\title{
Historical, Tactical, and Strategic Lessons from the Partition of Cyprus
}

\author{
Dan Lindley \\ University of Notre Dame
}

\begin{abstract}
This article surveys the history of Cyprus's conflict and partition to derive historical, tactical, and strategic lessons about how the Cyprus problem should be resolved and about the value of partitions more generally. Cyprus is complex. Tensions between North and South are very low, in part because the partition has been a cause of peace. However, both sides remain pervaded by antagonistic and one-sided biases, histories, and myths. Moreover, almost every plausible solution, including the Annan Plan, that proposes to unite the island also incorporates the group-based and gridlock-prone characteristics of the conflict-generating 1960 constitution. A Cyprus solution solves little and creates risks. A better plan to create a permanent peace is to recognize a much smaller North, and bring all sides including Turkey into the European Union. This would create peace, give most Greek Cypriot refugees their land and homes back, and restore all freedoms throughout the island.
\end{abstract}

Keywords: Cyprus, Turkey, Greece, United Nations, European Union, partition, security dilemma

There is a contentious debate about the value of partition as an extreme measure to reduce ethnic or internal conflicts. Oddly, the case of Cyprus is often cited by both proponents and opponents of partition. Who is right? On what grounds? And what do the answers tell us about the larger arguments about partition?

Furthermore, Cyprus remains a place whose geopolitical significance is far greater than its actual size or population. Resolving the Cyprus problem is a crucial component of Turkey's accession process into the European Union (EU). Resolving the Cyprus problem is usually assumed to mean dissolving the partition. Is this wise? What are the costs and benefits of doing so? How have the conditions that led to the partition changed?

In order to answer these questions, this article seeks to derive historical, tactical, and strategic lessons from the partition of Cyprus. After a review of the academic debate on partition, I first examine the pre-conflict history of Cyprus to shed light on how various factors ranging from British colonial policy, schools, and churches to extremist entrepreneurs laid the basis for the ensuing conflict. Although enmity between Greece and Turkey extends about as far back as any current rivalry, a significant part of the Cyprus conflict is attributable to manipulated identities, political expediency, and opportunism. The less profound and the more contrived the conflict, the more likely it is that the two sides can reconcile and pave the way for peaceful dissolution of the partition. The signs are mixed on both scores: the depth of the conflict, and the readiness of the sides to reconcile.

Second, I review the history of the Cyprus conflict and birth of the partition from the 1950s through 1974. In addition to deepening exploration of the issues just 
mentioned, the conflict period highlights the role of the security dilemma in driving the Cyprus conflict as both sides armed and then segregated into separate communities. Finally, this period shows how hard it is to design a constitution that simultaneously offers strong protections to minorities, that treats people as groups not individuals, and that does not also foster conflict. The Turkish Cypriots were given disproportionate representation in government and veto powers. This led to gridlock and friction with the Greek Cypriots. The main insight from this history is that the UN's Annan Plan, formally known as the "The Comprehensive Settlement of the Cyprus Problem," for resolving the Cyprus problem bears numerous and potentially ominous similarities to the 1960 Cyprus constitution.

Third, I assess the costs and benefits of the partition on tactical and strategic levels. Tactically, the buffer zone makes it much easier for the United Nations Peacekeeping Force in Cyprus (UNFICYP) to prevent and manage incidents. On the other hand, levels of tension have been fairly low since 1996 when the last spate of serious incidents occurred. On the strategic level, the partition helps clarify the local and regional balance of power. Turkey's overwhelming superiority is made clearer by its presence on the island, and by its presence in a clearly delineated location-both made possible by the partition. This presence provides security for the Turkish Cypriots, causes insecurity for the Greek Cypriots, and helps deter possible Greek Cypriot provocation.

Fourth, I survey the political complications of the partition and the Cyprus problem. They cause numerous headaches for the various countries and international organizations with stakes on the island.

So should the partition be dissolved, and North and South Cyprus unified? It is true that tensions and incidents have been lower than most might have imagined since the border was opened in April 2003. Moderate Annan Plan supporter Mehmet Ali Talat replaced rejectionist Rauf Dentash as leader in the North. On the other hand, there are some caution signs. As seen in the election of Tassos Papadopoulous and continued objections by some to bicommunal events, communal, as opposed to pan-Cypriot, nationalism endures. The Annan Plan contains many of the same flaws of the 1960 constitution. And prickly issues, especially disposition of property lost in 1974 and before, remain unresolved.

For these reasons, I see no need to rush to dissolve the partition. I support eventual resolution of the Cyprus problem for many reasons, including a vision of Muslims and Christians living together. However, I do not see why one should rush to fix something that is not much broken, especially when there are risks to premature unification. Instead, I hope that Turkey moves forward with its lengthy accession process into the EU Once Turkey is in the EU, and North Cyprus is recognized and also in the EU, the freedom of movement and property ownership provided will give Cypriots from both sides the chance to determine their own fates, and to reunify under the umbrella of the EU, if they so wish. This may take many years, but as is, each side sees itself mainly as a side, and not Cypriot. Perhaps the many years and many steps needed for Turkey and North Cyprus to enter the EU will help instill a European identity that will help reduce the dangers of premature unification.

\section{Theorizing about Partition}

A review of the academic literature on partition is useful because scholars have identified a number of factors, which should be considered when examining why the partition on Cyprus came about and when assessing the costs and benefits of maintaining the partition. For example, proponents of partition claim that the major benefit of partition is to reduce the security dilemma between adversarial groups. The benefit of a partition might logically depend on how much of a role the security dilemma played in the original conflict that led to the partition. 
While the literature provides a list of relevant variables to consider regarding the origins and effectiveness of partition, the utility of these arguments in this analysis is limited by several factors. First, there is little consensus in the literature on the causes of ethnic conflict. Inasmuch as prescriptions for resolving problems have to rely on accurate diagnoses, scholars have not found general covering laws for ethnic conflict, nor are they likely to. As a result, there is likely to be no general rule of thumb regarding partition as a general prescription for resolving ethnic conflict. Instead, the wisdom of partition is likely to depend on the sui generis characteristics of the conflict under analysis.

In part as a result of the difficulties diagnosing ethnic conflict, a second limiting factor is that there is no generalizable wisdom derived from the literature on partition. Proponents argue that partition reduces the security dilemma and can save lives. Opponents argue that partitions require a high blood price to establish, that the security dilemma may not drive many ethnic conflicts, and that partitions may make conflicts worse. To some extent, proponents and opponents have been talking by each other, and there is little of what might be said to be conventional wisdom emerging on partition (Bloom and Licklider 2004; Kuperman 2004).

Finally, reflecting the often polarized and nationalistic debates about Cyprus in general, debates are wide open whether the partition on Cyprus promotes peace or not. There are disagreements about how the Cyprus problem began, the history of 1955-1974, and whether or not the partition is just, or necessary, and whether the UN peacekeepers on Cyprus are actually promoting or preventing peace.

Despite these various problems, I proceed by summarizing the main arguments of partition proponents and opponents. I will then review the history of Cyprus and its partition with these arguments in hand, in order to see what light Cyprus sheds on these contentions. I am not trying to test the conflicting hypotheses on ethnic conflict and partition with this single case, but am using the theories and the case in tandem to see what insights they offer to each other.

The core of the debate on partition centers on the security dilemma. A security dilemma occurs when actions taken by one side such as buying arms or building fortifications hurt the security of the other side. The security dilemma explains arms races and rising tensions as both sides respond to each other's actions in a worsening spiral. The security dilemma assumes a prior level of tension or hostility, or the buildup would have no effect on relations. It is for this reason that Wendt (1995:73) argues that the United States fears five North Korean nuclear weapons more than 500 British nuclear weapons. Security dilemmas are relative, and do not simply exist or not. Instead, it is better to think as security dilemmas as something that can have little, some, or a lot of effect in worsening relations between adversaries. Many scholars believe that factors that favor the offense worsen the security dilemma while those that favor the defense mitigate the security dilemma. For example, mountains and oceans tend to slow offensives, while tanks and other fast-moving materiel are said to be primed for offense (Jervis 1978).

With regard to ethnic conflict, security dilemmas can be ferocious because it is so easy to kill one's neighbors. In contrast to states with borders and armies, intermixed populations have few defined borders, and often few external distinguishing characteristics. This porosity makes violence easy to perpetrate. Hence, when relations begin to slide downwards between intermixed adversaries, each side has much to fear, and it is relatively hard to put the breaks on (Posen 1993). Stuart Kaufman argues that it takes a combination of the security dilemma, hostile masses, and hostile leaders to spiral into ethnic conflict (1996).

If this is an accurate diagnosis of a major source of fuel in ethnic conflict, then policies such as partition that can separate adversaries may offer some promise of saving lives and bringing about peace. This is because it is harder to instigate conflict across more established borders, and easier to identify and confront 
aggressive adversaries (Kaufmann 1996). These defensive advantages can be further increased by buffer zones, and peacekeeping forces to monitor and deter the adversaries (Lindley 2004). Finally, the key proponent of partition, Chaim Kaufmann, offers a key limiting condition for the effectiveness of partitions. He says that the only time they will promote peace is when the separation of peoples is so complete as to eliminate the possibility that any lingering minority population could possibly threaten the minority, thereby eliminating the security dilemma. Carter Johnson (2006) offers compelling support for this proposition that complete partitions prevent war recurrence.

Critics of partition, and of the application of the security dilemma to ethnic conflict more generally, make a number of arguments. First, some argue that the security dilemma is not a big factor causing or exacerbating ethnic conflict. Instead, they argue that commodity economies, ideology, religion, and so forth are the largest drivers of conflict (Brown 1997; Crawford 1998; "Global Menace" 2003). As a result, there is little to reason to expect that partitions or other measures that lessen the security dilemma will do much to ameliorate the underlying causes of conflict. Partition may simply transform an internal conflict into an international conflict between the newly formed countries.

Second, it is possible that intermixed communities are a source of peace, rather than being a source of conflict susceptible to the security dilemma. For example, in multiethnic societies where politicians need the backing of different groups to win, politicians will have to appeal widely across groups. Such appeals are likely to offer benefits to all groups, and to avoid divisiveness. Some intermixed communities may find they have too much in common from economic interdependence to cultural attributes to find reason to fight, much less wish partition (Fearon and Laitin 1996; Varshney 2003; Laitin 2004; Roe 2004; Wilkinson 2004).

Third, partitions may be costly in terms of lives saved and in terms of justice. Partition is tantamount to ethnic cleansing, and such cleansing may well be an extension of the war the partition is meant to stop. In addition, on what basis does any state or the international community tell families, villages, or regions to pick up and leave their homes? People are often willing to fight and die for their homelands, so saving lives may not be the highest value for these people (Betts 1994; Fearon 2004). Finally, who is to say where the partition line should go? A partition line may lead to further conflict, which may be worsened by the next problem, below. And this links back to the problem about the causes of the conflict in the first place. If the conflict is caused by ideologues and hard liners, the partition line may become part of the rallying cry that keeps them in business.

Fourth, it is not a mere definitional issue that internal conflicts may become international conflicts. When a state fragments into partitioned segments, each new country will have its own foreign policy and due to the more narrowly defined interests of the new parts (religious, ideological, and so forth), the new states may well find allies who are opposed to the other new state/s on the other side of the partition. In this way, a partition may expand an internal conflict into a broader international problem.

Fifth, another international dimension is that partitions may cause poisonous precedents. Even if a partition may save lives in one case, it may inspire additional separatist rebellions. Opponents of partition frequently point out that the number of possible subgroups in the world is huge, and would threaten the current system of sovereign states (Fearon 2004; Laitin 2004).

A final objection to partition is what might be termed the "frictional costs" to the international community. These costs involve the agenda time devoted to trying to resolve the underlying conflict, and to dissolving the partition. Financial costs may also result from peacekeeping and/or international support costs to one or both sides, as well as those costs related to diplomatic initiatives and conflict resolution (Kumar 1997). It is important to remember in the context of the last two 
points that war is itself a bad precedent, and that trouble spots of all sorts cause frictional costs.

In sum, the literature on partition leads me to try to answer the following questions when analyzing Cyprus:

- What was the role of the security dilemma in causing the conflict?

- Did the partition reduce the security dilemma?

- What is the history of intermixing on Cyprus and what have been its effects on intercommunal relations?

- What do bicommunal activities and the opening of the inner-Cyprus border tell us about the future of intermixing?

- Do new solutions for the Cyprus problem help resolve past problems with intermixing?

- Is the partition a source of conflict itself?

- Are injustices associated with the partition a source of conflict?

- What have the effects of the partition been on regional and international politics?

\section{History of Cyprus: What Led to the Partition?}

\section{Pre-1955: Laying the Foundation for Intercommunal Violence}

Although hostility between Greeks and Turks is literally ancient, I begin with the period of Turkish rule of Cyprus from 1571 to 1878 . Turkish rule led to several important developments. First, it brought Turks to the island in larger numbers, creating ethnic heterogeneity. Second, the Greek Cypriots turned to their church as a source of continuity and security during occupation (Markides 1977). The Ottomans reversed the previous persecution of the Orthodox Church by the Venetians, and made the Church the governing body for non-Muslim subjects on the island (Attalides 1979). Third, confiscatory and discriminatory colonial policies by the Turks helped bolster Greek Cypriot nationalism and fostered dreams of enosis, or unification with Greece (Keefe and Solsten 1993).

Enosis, and the Turkish Cypriot notion of Taksim or partition, are at the root of the Cyprus problem. They are a dramatic threat to the other group, and they are mutually exclusive. They represent a security dilemma of sorts. The closer one group gets to or pushes for unification with their "home" countries or partition, the more it threatens the other group.

Intercommunal tensions were not high when the British took over administration of the island in 1878. However, as Joseph (1997:16-18) notes, "Despite four centuries of coexistence and considerable physical intermingling, the two communities remained separate and distinct ethnic groups," whose bonds were not deep enough to overcome the divisive forces tensions to come. There was an "absence of intermarriage, and ... limited participation in joint social and cultural events" (Joseph 1997:29).

A story often told by Greek Cypriots who wish to dissolve the partition is that the Greek Cypriots and Turkish Cypriots treated each other as brethren, often sharing coffee, and so forth. The motivation for this view of history is to promote a Cyprus solution by addressing the concern of skeptics that the two groups cannot live peacefully together. The truth is more complex in that the two groups did live peacefully together, but more separately than as brethren. Meleagrou and Yesilada (1993:85) describe this as a "love-hate relationship."

Over time, schools, churches and British colonial policy laid the ground for heightened ethnic tensions on Cyprus. Although there was a some sense of shared Cypriot identity among the Turkish Cypriots and Greek Cypriots, the shared part 
eroded over the early 1900 s, was battered from 1955 to 1960 , and was all but crushed in the violence of 1963-1974.

To briefly explain this evolution, each community had their own school system, with separate boards of education. The schools emphasized the differences between the Greek and Turkish Cypriots. "The two groups were encouraged to view themselves as extensions of their respective motherlands, and the development of two distinct nationalities with antagonistic loyalties was ensured" (Meleagrou and Yesilada 1993:57).

For example, the schools were seen as a central mechanism for promoting Hellenism and Greek identity within the Greek Cypriots. A major goal of education was to indoctrinate students about enosis and to "inculcate in the young the need to expand the limited borders of the Nation" (Attalides 1979:26; Bryant 1998b). The church retained control of most of the schools and hired teachers from mainland Greece. Greek Cypriot schools consistently refused British funding on the basis that it would force them to conform to British standards of education. The Bishop of Kition threatened to excommunicate any who sent their children to the English school or the American School at Larnaka. However, in 1935, in the wake of enosisoriented violence, the British took control of the education system and set intercommunal standards. This did not work too well, as between 1955 and 1957 the British shut down the schools of five-sixths of Greek Cypriot schoolchildren using the justification that schools encouraged indiscipline as "centres for the organization of lawlessness, riot and violence" (Bryant 1998a:469).

Pro-enosis and anti-Turk rallies go back as far as 1912. In 1931, a crowd of 5,000 rallied for enosis and against British rule and taxes under the direction of priest Dionysios Kykkotis and ended up burning down the governor's house (Attalides 1979; O’Malley and Craig 1999). Greek Cypriot hopes for enosis were raised by Britain's World War II recruiting slogan in Cyprus: "Fight for Freedom and Greece" (Kyrou cited in Attalides 1979:a23). In 1950, as part of bishop Makarios's efforts to further boost the role of the church and promote union with Greece, he held a referendum on enosis within the Greek Cypriot community. Faced with excommunication if they did not participate, almost $96 \%$ of the Greek Cypriots voted for enosis. Later that year, Makarios became Cyprus's archbishop and de facto political leader of the Greek Cypriots. His major goal was enosis.

On the Turkish side, Turkish Cypriot nationalism was less strong at first, due to poverty, and fears of isolating the British. Following World War II, the Turkish Cypriots began to organize politically, both as a result of their own growing Turkish nationalism, and in reaction to the growing calls and protests for enosis. Fear of domination by the Greek Cypriot majority and of eventual union with Greece motivated Turkish Cypriot calls for taksim, partition of the island into separate Turkish and Greek states. The British also used "divide and conquer" tactics, that helped destroy the chances of achieving a common Cypriot identity. For example, in 1919, at a time when Turkish Cypriots made up 20\% of the population, over half of the members of the Cyprus police force were Turkish. Later, in 1955, the British created an auxiliary police force of Turkish Cypriots to help fight the Greek Cypriot EOKA (National Organization of Cypriot Fighters) rebellion (Keefe and Solsten 1993; Joseph 1997; Bryant 1998a). Attalides (1979:40) argues that, contrary to the claims of many Greek Cypriots, Turkish Cypriots did have a consciousness distinct from Greek nationalism (see also Joseph 1997).

The foundation was laid for intercommunal conflict in two main ways. The first is the emergence of different and wholly incompatible views for the future of Cyprus: enosis and taksim. The second is the merging of church, schools/education, and politics in divisive and nationalistic ways. This is true on both sides, but is particularly virulent on the Greek Cypriot side. Hopes for a pluralistic and unified society are dim when the majority side offers little basis for inclusiveness. Moreover, profound aspects of the Cyprus problem such as territory and ethnic identity are 
apparently indivisible. Because of their all-or-nothing nature, indivisible disputes are more prone to violence and are among the hardest to resolve (Toft 2003).

\section{From 1955 to the Partition Resulting from the 1974 Turkish Invasion}

The Greek Cypriot revolt against British colonial rule broke out in full force in 1955. Archbishop Makarios led the Greek Cypriots politically, while General George Grivas Dighenis led the underground EOKA fighters. As mentioned, the British responded in part by forming Turkish Cypriots into a police force to help fight EOKA. In 1956, the Turkish Cypriots formed Volkan, which later became the Turkish Resistance Organization (TMT), to counter EOKA. Some 600 people died in the ensuing fighting which combined EOKA attacks on British military and civilians, attacks between EOKA, TMT, and their respective sides, as well as attacks by EOKA and TMT on their own sides against sympathizers, informants, and leftists. Although the absolute number of casualties may seem small to outsiders, Cyprus is small, so 600 dead on Cyprus is roughly proportional to 300,000 Americans dead (The 1960 population of Cyprus was almost 600,000 (Joseph 1997:16), meaning casualties of about .1\%). Thus, this apparently small conflict "implanted a bitterness in both ethnic communities and foreshadowed postindependence strife" (Attalides 1979; Tartter 1993:214-215).

A cease-fire followed Cyprus' gaining of independence in 1959-1960, and Cyprus enjoyed 3 years of relative peace. The Zurich and London Agreements of February 1959 set forth the terms of independence by laying out the basic provisions of the future constitution of Cyprus, and specifying three treaties to govern future relations between Britain, Cyprus, Greece, and Turkey. The constitution contained a variety of problematic clauses, including various quotas that disproportionately favored the Turkish Cypriots, and veto provisions for each side. These features are discussed in more detail below, but suffice it to say that these provisions heightened tensions, and as tensions increased, the veto powers led to government gridlock.

The first treaty, the Treaty of Establishment, allowed the British to keep two military bases on Cyprus in "sovereign base areas." This fact guaranteed that the British would be prominently involved in future diplomacy regarding Cyprus. The second treaty, the Treaty of Alliance, provided for a Greek military presence on the island of 950 soldiers, and a Turkish presence of 650 soldiers. It also specified that the contracting parties would cooperate in defense matters, provide for the defense of Cyprus, and that Greece and Turkey would jointly train the future Cypriot military. Finally, the Treaty of Guarantee prohibited both Cyprus's union with any state (enosis) as well as partition (taksim). It further specified that Britain, Greece, and Turkey were the guarantor powers of the independence and unity of Cyprus, and that they had the right to act jointly or independently to restore the status quo (i.e., to prevent enosis or taksim) (the Zurich and London Agreements 1959). The latter two Treaties nearly ensured that any conflict on the island would involve Greece and Turkey.

The biased and unwieldy constitution proved to be the catalyst for intercommunal violence. To fix the problems in the constitution and its shaky implementation, President Makarios proposed 13 points on November 30, 1963, which would have reduced or eliminated the Turkish Cypriot veto and quotas. The proposals were rejected by Turkey on December 16. Fighting broke out on December 21, starting in Nicosia, and quickly spreading (Salem 1992; Keefe and Solsten 1993; Laipson 1993). The United Nations Peacekeeping Force in Cyprus (UNFICYP) was deployed in March.

Communal violence waxed and waned over the years, with the biggest crisis occurring in 1967 when Turkey almost invaded. The effects of the fighting on Cyprus' demography are described in the next section. Following their own coup, a Greece-inspired coup against President Makarios on July 15, 1974, led to EOKA 
leader Nicos Sampson becoming president. This put an end to the relative calm since 1967, and Sampson's presidency meant that enosis was imminent. Turkey invaded on July 20 to protect Turkish Cypriots in the midst of the turmoil and to prevent enosis. Within 3 days, the Greek junta in Athens as well as Sampson were out of power. Despite the opportunity to resolve issues on Cyprus with the new government/s, Turkey continued to expand their hold on Cyprus until in midAugust it controlled $37 \%$ of the island.

Turkey's invasion was initially legal under the Treaty of Guarantee, but soon became illegal under the same treaty as it became apparent that the status quo would not be restored. From the points of view of law and of proportionality, Turkey took too much and stayed too long. However, the invasion did create the partition that has lasted to this day.

About one-third of the Greek Cypriot population became refugees as they fled southward from the Turkish invaders. Later, about one-third of the Turkish Cypriot population moved North into the new Turkish sector (Laipson 1993:142). The resulting Greek Cypriot South and Turkish Cypriot North ended up being almost completely homogeneous.

\section{Security Dilemma over Time}

If the security dilemma plays a big role in ethnic conflict, what might we expect to see as a result? One observable implication would be changes in ethnic demography. If insecurity is higher and attacking easier when communities are intermixed, then we should expect those who are most vulnerable to try to get away from their adversaries, to concentrate themselves, and to reduce the amount of intermixing. Arms races may also occur between the adversarial communities. This is what is beginning to happen in Iraq (Gettleman 2006; Knickmeyer 2006). And it is precisely what happened on Cyprus. Indeed, it is hard to think of a better example of the security dilemma affecting demographics.

As can be seen in Table 1, the number of mixed villages was substantial at $43 \%$ when the British arrived. The number of mixed villages shrinks over time, while the Greek Cypriot villages grow. These trends accelerate as hostilities increase, especially during the interval from 1960 to 1970, and the Turkish Cypriots become more concentrated.

Figure 1, Ethnic Demography on Cyprus, puts a finer point on these developments as it shows that, within the course of the 4 years of December 1960 through December 1964, the pastiche of mixed, Turkish, and Greek villages have been replaced by swaths of Greek-dominated areas. Most Turkish Cypriots came to live in enclaves, especially after violence accelerated in late 1963.

Although the movement of the minority Turks into more and more defensible positions is what security dilemma theory would predict, some on the Greek Cypriot side argue that this is not, in fact, what happened. Instead, as the counterargument goes, the Turkish Cypriots moved themselves into enclaves either

TABLE 1. Ethnic Population Segregation from 1891 to 1970 (Adapted from Patrick 1976; Calotychos 1998)

\begin{tabular}{lccccccr}
\hline Year & Mixed Villages & G.C. Villages & T.C. Villages & \# Villages & \% Mixed & $\%$ GC & $\%$ TC \\
\hline 1891 & 346 & 342 & 114 & 802 & 43 & 43 & 14 \\
1931 & 252 & 358 & 84 & 694 & 36 & 52 & 12 \\
1960 & 114 & 392 & 117 & 623 & 18 & 63 & 19 \\
1970 & 48 & 444 & 11 & 503 & 10 & 88 & 2 \\
\hline
\end{tabular}

G.C., Greek Cypriot; T.C., Turkish Cypriot. 

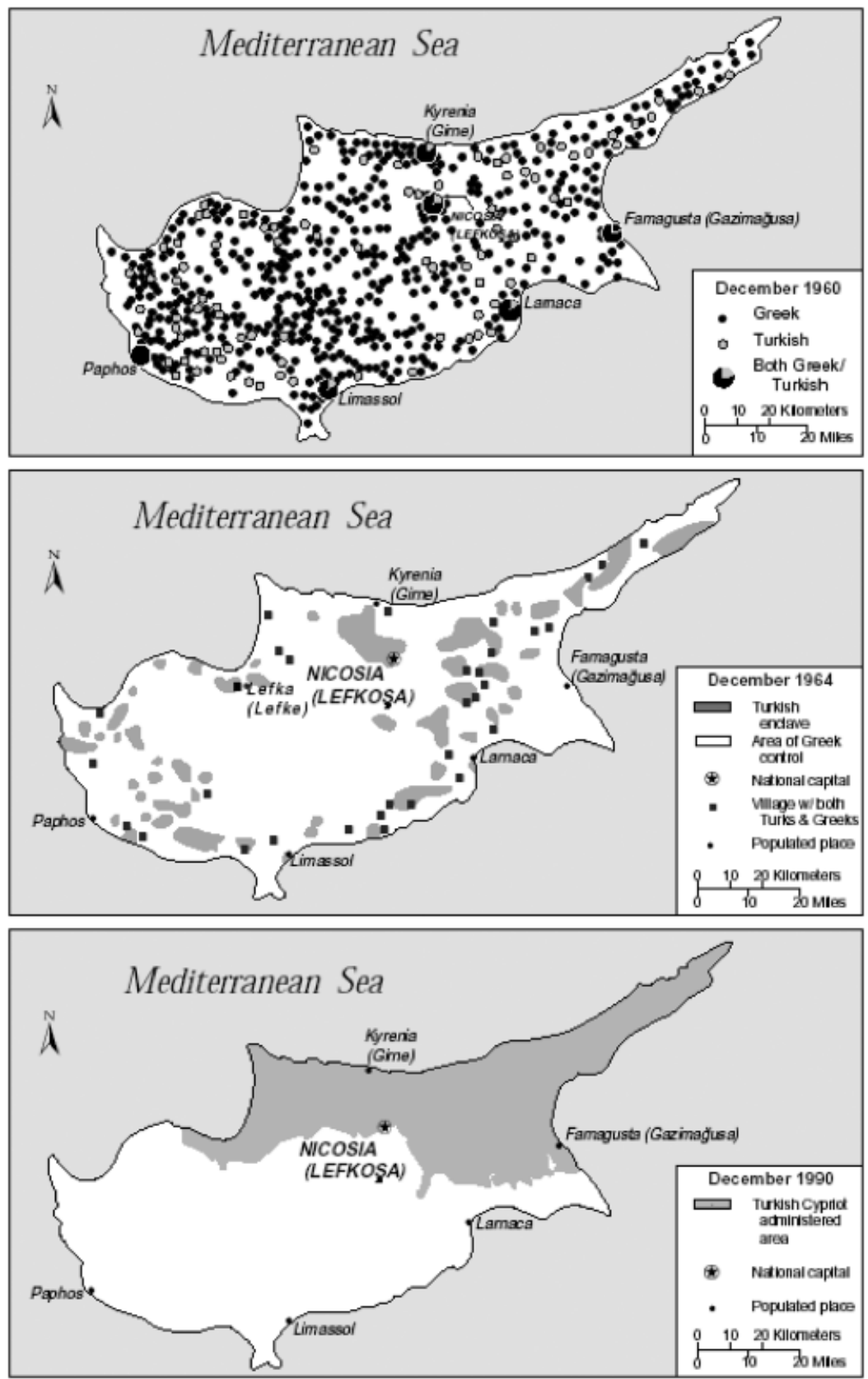

FIG. 1. Ethnic Demography on Cyprus (Meleagrou and Yesilada 1993:56; U.S. Library of Congress 2006, Cyprus)

inexplicably or to increase political control over their side. As a result, Greek Cypriots living in these new enclaves were expelled. One of the main themes in this version of history is that it was not the Greek side that encouraged the partition. As Andreas Theophanous (2002:44) writes, the Turkish Cypriots "formed their own enclaves, to which the majority of the Turkish Cypriots moved" (see also Sambanis 2000:464; Fouskas 2005:54). A main motivation for this line of argument is that the Greek Cypriots - who generally claim to want to dissolve the partition and reunify 
the island - do not want to be responsible for anything that would reify or justify partition in any form.

This rendering of history is largely inaccurate. When heavy fighting broke out in December 1963, both sides were more than ready because they "had already been stockpiling arms since the declaration of independence" (Joseph 1997:31). Although there were occasions when Turkish irregulars forced Turkish Cypriots into enclaves, by far the majority "fled to safer areas because of the treatment they had received from Greek irregulars." The security argument is further bolstered by the sacrifices many Turkish Cypriots made to move. Many of the Turkish Cypriots ended up "badly off for both food and medical attention" (Purcell 1969:335). Both sides engaged in competitive building of fortifications, and expansion of security zones through 1967, though the Greeks side pressed harder than the Turkish side (Purcell 1969:375).

Richard Patrick's authoritative account on the Cyprus conflict notes that:

\begin{abstract}
The author's investigations reveal that the overwhelming majority of TurkCypriot refugees moved only after Turk-Cypriots had been killed, abducted or harrassed by Greek-Cypriots within their village, quarter, or in the local vicinity. Most refugees expected to return to their homes within a few months at the most, and it was this assumption of an early return that facilitated their departure in the first place .... In some instances, the evacuation of certain villages was encouraged by the expectation of an imminent invasion by Turkey. There was an understandable desire to withdraw from Greek-Cypriot areas which might become bombing targets of the Turkish air force. It was only in a few instances, after January 1964, that the Turkish-Cypriot Leadership took the initiative in recommending that certain villages should be evacuated. .... Generally, Turk-Cypriot refugees moved en masse to the nearest Turk-Cypriot village or quarter that was guarded by Fighters. In most cases, refugees fled from their homes, leaving clothing, furniture and food behind. Most of the abandoned villages and quarters were ransacked and even burned by Greek-Cypriots. .... In review, the pattern of refugee movement was not one that seems to have been designed to facilitate partition (Patrick 1976:45-88).
\end{abstract}

The story of the coup leading to threat of enosis and triggering the Turkish invasion highlights another form of near perpetual insecurity on Cyprus. The Turkish Cypriot minority fears the Greek Cypriot majority, while the Greek Cypriots fear nearby Turkey. Unless a fundamental peace is achieved, these overlapping insecurities are unstable and will continue to cause tension. Also, as mentioned above, much about the Cyprus problem is indivisible.

\title{
Costs and Benefits of Partition
}

\section{Tactical Effects}

The partition has greatly pacified relations on the tactical level between the two communities on Cyprus. By tactical, I refer to day to day incidents of violence that are bad in and of themselves and have a possibility to escalate. On the tactical side, the effects of partition are striking in two ways. First and most importantly, peacekeeping is much easier post-1974 than pre-1974. Second, there are far more incidents for UNFICYP to deal with where the buffer zone is narrower (around Nicosia, for example) than where it is wider and the opposing forces have less opportunity to harass each other. Not only does partition help peace on a tactical level, but also a wider partition is more effective.

UNFICYP started off with almost 6,400 soldiers in Spring 1964, and deployed along the Green Line which already separated Nicosia into Turkish and Greek Cypriot areas, in towns where trouble was expected, and throughout Cyprus more generally which UNFICYP had divided into six zones. Although it was difficult for 
peacekeepers to cover the island, most observers believe the UN did a good job of preventing and tamping down conflict. In addition to the peacekeepers, between 1964 and 1967, the Greek Cypriots and Greeks had roughly 33,450 men under arms on Cyprus while the Turkish side had 13,450. It is perhaps remarkable that an Aegean-wide war did not start with the combustible mixture of forces.

As noted above, Turkish Cypriots moved and were forced into enclaves. This meant that UNFICYP patrolled a number of de facto mini-partitions throughout the island. In addition to the enclaves, tensions and fighting also helped create lines between the communities. These lines in turn made it easier for UNFICYP to figure out where to interpose its forces when conflict loomed. Indeed, sometimes UNFICYP tried to clarify the local cease-fire lines with paint and large rocks. Both the enclaves and the efforts of UNFICYP to reify them support the security dilemma argument that clear lines improve security between adversaries, whereas haphazard intermixing poses more threats. The current formalized buffer zone is better at separating antagonists than these rudimentary efforts (Stegenga 1969; Harbottle 1975; Birgisson 1993; Lindley 2001).

Since 1974, there have been fewer than 20 deaths in and along the buffer zone, including a spate of five in mid-1996. Since 1974, the number of peacekeepers declined to between 2,500 and 2,000 up to the early 1990s, when the force was reduced to about 1,200. Recently, the force was reduced again to around 900 . The ever-smaller force is a symptom of increasing relative peace along the buffer zone. Recent Reports of the Secretary-General on the United Nations Operation in Cyprus indicate a general decline in the number and seriousness of incidents along the buffer zone, down to some 60-80 a month, with most not constituting a threat to security (UNFICYP 2005). Routine incidents include things like insult or search lights being used to harass from one side to the other. Less routine and more serious incidents involve shots being fired or opposing forces entering the buffer zone.

Although most incidents are not serious, UNFICYP still functions well in and along the buffer zone to reduce the chance of conflict. I view this using a roulette wheel analogy in which incidents spin the wheel of war, but the odds of conflict are reduced by UNFICYP's actions. See Lindley (2001) for an analysis of how UNFICYP works on a daily basis - although they use a more mobile patrol concept now.

\section{Strategic Implications of Partition}

The strategic implications of partition are linked to the tactical situation in that wars resulting from the Cyprus problem may result from tactical incidents and misunderstandings. A larger issue may be what would happen if the partition was dissolved and troubles returned to Cyprus. As is, the Turkish forces on Cyprus could conquer the island in perhaps 3 days. There is no doubt that, even after troop reductions resulting from a solution, Turkey will retain perpetual strategic superiority on the island. There is little that any dogma or alliance between Greek Cypriots and Greece will do to help Greece be able to meaningfully defend Cyprus. Without comment on justice and legality issues, it is the Greek side that has claims against the Turkish side, hence the current balance is good for deterrence as it favors the status quo side, not the revisionists. Again, I do not mean this as a comment about what the status quo should ultimately be.

I examined the strategic issues surrounding Cyprus at length in 1997 and one of my main arguments was that a premature Cyprus solution that might lead to a recurrence of troubles would also lead to a recurrence of 1974, due to Turkish superiority (Lindley 1997). Such a war would be traumatic for Cyprus, of course. It would also likely represent a near permanent setback for Turkish hopes of EU accession-even if they did not start it. It would greatly complicate diplomacy for the EU, for the United States, for NATO, add to the climate and reality of instability hanging over the Middle East, and hurt the cause of peace between Christians and 
Muslims more generally. As before, a war on Cyprus would be a disaster reaching far beyond the island itself.

In the end, the partition cuts in multiple directions. It creates a lingering wound between the Greek Cypriots and Turkish Cypriots, as well as between Greece and Turkey. On the other hand, by minimizing contact between the sides, it prevents a recurrence of past troubles. It also crystallizes Turkey's strategic and deterrent superiority.

An argument might be that things have been so peaceful for the last 10 years that a solution is more easily envisaged and that Turkey's forces are superfluous. I will cover the current situation in more detail below, but one reason things are more peaceful is that the Republic of Cyprus lost its gambles in 1996 and 1997 to try to increase tensions and exploit resulting international concern and help provoke movement toward a settlement. Thus, some of the current peace is due to the Republic of Cyprus's failures in trying to "internationalize" the Cyprus problem.

To develop this point, in 1996, the Republic encouraged a massive motorcycle demonstration against the North, and helped the motorcyclists break through the buffer zone into the North. The consequences were fatal as the Turks beat one demonstrator to death, and Turkish Forces shot another to death in the buffer zone after the funeral of the first. While no Greek Cypriots should have died, it was reckless of the Republic of Cyprus to encourage a demonstration that was bound to be violent in the first place. Greek Cypriot encouragement was public knowledge, was protested by diplomats, and was the subject of several UN reports. Because of this, the Republic gained little sympathy. The tactic of stirring up trouble backfired because it was illogical to try to use violence create an atmosphere where reunification seems to be a good idea. In 1997, the Republic of Cyprus announced plans to purchase advanced S-300s from Russia. Again, part of the motive was to focus international attention on the island. Turkey threatened to attack the missiles if they were deployed. In the ensuing diplomatic furor, Cyprus was forced to back down, and the missiles were never deployed (Lindley 1997). Cyprus lost face in both cases, learned its lesson, and has since not resorted to forceful provocation.

I do not mean to excuse Turkey's strong-arm tactics in these incidents, although they paid off in the short run (I critique Turkey's brutish behavior in Lindley 1999). There is no doubt Turkey is tough. However, it too has paid a price in the international community in both these cases. In the long term, such behavior is counterproductive. If Turkey focused more on being constructive and integrating more, it would reap a number of economic and strategic benefits, including increased security (Lindley 1999).

In sum, a peaceful stalemate has emerged. The Republic loses face if it stirs up problems, and if things descend into conflict, then there is no question that Turkey will win.

\section{Political Ramifications of Partition}

The Cyprus problem creates an ongoing headache for all the states and international organizations who have become enmeshed in the situation. To try to summarize a very complicated situation with many layers, the partition helps divide Greece and Turkey. This division means that the British, a former colonial power with bases on Cyprus, and the United States, whose NATO allies include Greece and Turkey, have to tread gingerly to manage their strategic interests and are inevitably drawn into the seemingly perpetual negotiations over the Cyprus problem. For its part, the UN is the point-organization for the Cyprus negotiations, which consumes disproportionate resources from the Secretary-General and his good offices. Finally, the EU has bungled badly in dealing with Cyprus in its successive accession negotiations with Greece, Cyprus, and Turkey. Fearing importing the Cyprus problem into the EU, but caught between a rock and a hard place, the 
EU tried and failed to use its leverage over Cyprus before letting it accede into the EU. If the EU had made solving the Cyprus problem a precondition for the accession of Cyprus, it would have given Turkey veto power over accession for the Republic of Cyprus. On the other hand, when it abandoned solving the problem as a precondition for accession, the EU gave up its leverage on the Republic of Cyprus (Lindley 2003). Unfortunately its leverage evaporated just when the Republic elected a nationalist president opposed to the Annan Plan.

The Cyprus problem is a headache because of the various tensions it causes, but trying to solve the problem is itself a headache. At times it seems like some in the international community are more interested in managing the Cyprus problem than in resolving it.

\section{Looking Toward the Future: Reunification or Continued Partition?}

I believe that the above points, while complex, generally tend to support continued partition in the short term. Some points in favor of reunification are that the problems that caused communal conflict largely resulted from deliberate policies of the two communities and by Britain. There lacks the sort of ancient hatreds one might assume would exist between these communities. They were able to live together peacefully, if not comingled. So, in theory, it should be possible for policies to be formed that would heal these divisions.

On the other hand, the cautionary signs are multiple. The divisions took decades to create, and they cannot be undone quickly. Moreover, despite the bicommunal activities promoted by the UN and others, it is hard to judge their effects. They seem like a drop in the bucket compared with textbooks that have yet to be rewritten to become less biased, to ongoing propaganda and one-sided versions of history (some of which were highlighted above), and lack of political will to try to compromise. Many on the Greek Cypriot side oppose the bicommunal activities.

The partition and history leading up to it are as close as realistically possible to a textbook case of security dilemma-driven behavior and results. Although Cyprus has its idiosyncracies, the security dilemma drove people apart, and a good amount of the subsequent peace can be explained both tactically and strategically by the partition and buffer zone. This case supports the theories of partition proponents.

These are fairly general points, but several more specific arguments can be made in favor of the status quo for now. First, support for reunification is fading on the Greek Cypriot side. Second, the Annan Plan recreates almost all of the problems of the 1960 constitution. Hence a Cyprus solution may fix a problem that is not overly severe and is getting smaller anyway. And it will replace a fairly stable partition with a politically difficult constitution that will only work if there is significant goodwill on both sides. Third, no one has yet to resolve the difficult issues surrounding property losses, return, and compensation. These issues may be precisely the kind of thorn that comes back to exacerbate communal relations and in turn make the constitution harder to implement. It is not wise to fix a small problem by replacing it with a risky solution.

Supporters of reunification point to the relative peace that has prevailed since the opening of the inter-Cypriot border in April 2003. And indeed, there have remarkably few incidents generated by large flow of Cypriots to each side. If violent racism were prevalent, one might expect more violence.

But if familiarity is not breeding contempt, nor is it breeding harmony. A troubling sign is that despite the general claim of the Greek Cypriots to be in favor of a unified Cyprus, $48 \%$ of the Greek Cypriots would prefer to live separately from the Turkish Cypriots, while $43 \%$ prefer co-existence. The younger the age group, the less they prefer co-existence. Sixty-three percent of Greek Cypriots between ages 18 and 24 are against co-existence, while $61 \%$ of those aged 65 and up support living together. Moreover, the overall percentage of Greek Cypriots wanting uni- 
fication has dropped "dramatically" since 2003, the year the North opened the buffer zone to free travel. An analyst in the newspaper story covering this Cyprus Broadcasting Corporation survey blamed the Tassos Papadopoulos regime for declining support for unification, as well as continued incitement of hostility toward the Turkish Cypriots in schools. On the positive side, opinions of the Turkish Cypriots by the Greek Cypriots have risen over time (Leonidou 2006). I think these numbers also mean that the Cyprus problem is lessening over time. The younger generations do not view the Cyprus problem as an issue warranting political cost and compromise. It is the older generation who wants their property back, the youth care less about that, and they care less about 1974 and prior problems.

While it is true that the partition continues to create heartache for those who lost their homes in the 1960s and in 1974, it is natural that this motivation for a solution is felt less strongly by the young. As the population ages, this is a problem that shrinks. As it is the Greek Cypriots that have historically promoted a Cyprus solution and are this sense this revisionist side, as time goes by there is both less imperative for a solution, and apathy also reduces the risks in the current status quo. Although I argue that the schools, propaganda and other forces create divisiveness, they have not fully stopped the tide of apathy and satisfaction with the status quo. This raises the question: Why take risks and pay political costs for people who increasingly do not care, and do not want co-existence?

\section{The Annan Plan: 1960 Revisited?}

The Annan Plan was proposed in 2002 by UN Secretary-General Kofi Annan and was designed to create a Swiss-style confederal system. It has many facets, including the following similarities with the problematic 1960 constitution.

As a confederation with various specified provisions, the Annan Plan treats the Cypriots as two distinct communities. This may be necessary and expedient, but it has already caused resentment by the Greek side. Considering the terms of the plan discriminatory, the Greek Cypriots resoundingly rejected the plan in a referendum in April 2004 with the no side getting almost $76 \%$ of the vote. The Turkish Cypriots voted in favor by almost $65 \%$ (BBC 2004). The writing was on the wall on both sides: the Greek Cypriots had elected a solution rejectionist over a year before the referendum. In contrast, the rising Mehmet Ali Talat on the Turkish Cypriot side helped prod the favorable Turkish Cypriot vote.

This situation is difficult for many reasons. The Annan Plan was the result of years of work by the international community, and yet still did not unite Cypriots around a common future. To think of reunification without a common vision, and with the problems mentioned before, means that it is natural that the above constitutional terms will be controversial. And yet they are inevitable because if the Turkish Cypriots are treated by Greek Cypriots and the international community as a group instead of as individual Cypriots (and the same goes for the Greek Cypriots), then they will need the sorts of controversial minority protections provided for in the Annan Plan.

The conundrum is: how to provide for minority rights if they actually need protecting, without making things worse? The best way around this problem is to have a common Cypriot identity so that people are treated as individuals, not as part of groups. However, there is no precedent for this in Cypriot history, even during the period of peaceful co-habitation. While it is possible that the two sides could live peacefully under a new agreement, any agreement foreseeable will contain the seeds of its own 1960s-like implosion.

The Annan Plan even recognizes this in a roundabout way. It reinforces the partition in that it allows for only partial reintegration of the communities, and only 
Table 2. 1960 Constitution vs. Annan Plan

\begin{tabular}{cc}
\hline Issue & Annan Plan: United Cyprus \\
Republic
\end{tabular}

Group-Based Vetoes

Group-Based apportionment

7:3 Deputies ratio in House of Representatives

7:3 ratio of GC to TC ministers

7:3 civil service ratio; $6: 4$ armed forces service ratio

Court apportionment

Supreme Court: 1 GC judge; 1 TC judge; 1 external/neutral judge with two votes

Other group-based characteristics
Presidential Council decisions need a simple majority but must have the vote of at least one member from each group Parliament can pass bills with simple majorities of both chambers, so long as $1 / 4$ (sometimes 2/5 "special majority" for certain matters) of the Senators from each group vote in favor

Special majority needed to elect the Presidential Council

Equal GC:TC ratio in Senate $(24+24=48)$

Proportional ratio in Chamber of Deputies, but TC's get a minimum of $25 \%$. (36

$\mathrm{GCmax}+12 \mathrm{TCmin}=48)$

TCs get a minimum of two of the six seats in the Presidential Council, of which one will be in charge of either foreign affairs or European affairs. GCs get 2 terms as President of Council for every 1 TC term

Rotating Presidency and VicePresidency

One-third of the federal public service must hail from each constituent state

Supreme Court: 3 GC judges; 3 TC judges; 3 external judges

(Note: can resolve govt

deadlock in some cases)

\begin{tabular}{ll}
\hline Federal Police & $\begin{array}{l}\text { Equal number from each constituent state. (which will put a lot of TC } \\
\text { police into the South) } \\
\text { Board consists of } 1 \text { member from each constituent state, with a third } \\
\text { who maybe a non-Cypriot }\end{array}$ \\
Attorney General & AG and Deputy AG must be from different constituent states; same \\
for Auditor General & Two members from each constituent state, three from an outside, \\
Property Board & non-guarantor power state \\
Taxes & Indirect taxes to flow into TC side until inequalities eliminated \\
\hline
\end{tabular}

Table is expanded from Lindley (2003:50).

on a delayed and very gradual basis. This is wise, but also an yet another indication that a full dissolution of the partition is thought to be premature at best by the international community.

Another factor that complicates a possible solution is whether and how many displaced Cypriots will be able to return to their original property. As mentioned 
above, many Cypriots from both sides were displaced by the violence from 1963 through 1974. This raises the issue of what to do with property abandoned and subsequently re-occupied in the enclaves and then in the 1974 invasion? The Annan Plan reduces the size of the Turkish area down to 29\% (from 37\%). This displaces Turkish Cypriots in about 60 villages, but allows about two-thirds of the 180,000 displaced Greek Cypriots to return, if they wish. The plan allows only a limited amount of Greek Cypriots to return to the Turkish Cypriot area, and includes a complicated and vague system for compensating those on both sides who cannot return. It is unclear how property values will be evaluated for compensation, and a mixed member property board (see Table 2 ) will ultimately make these decisions. Although the proposed system could possibly work smoothly, its flaws make it more likely to generate substantial disappointment and anger (www.cyprusdecides.org; UNFICYP 2005). Even if the compensation board did start to function, its decisions would like anger as many people as they satisfied, and compromises may leave all dissatisfied. Every decision will cause pain, and there will be many iterations of pain over time.

\section{Conclusion}

The Cyprus problem is a headache for the international community. But strategically and tactically, the problem is lessening with time. Although outright violence is a fairly recent phenomenon in terms of the history of Cyprus, partition has greatly lessened conflict between the communities. The peaceful opening of the border in 2003 provides some hope that dissolving the partition and living together would work out. However, why take the risk, when several factors suggest serious risks in reunification?

There is insufficient common identity as Cypriots on both sides. The best odds for a solution are when both sides think they are Cypriots first, and Greek Cypriots and Turkish Cypriots second. As is, communal identities trump common identity. This means that any solution based on these differences will likely foster tension because such a solution will be based on group distinctions and risk a replay of the disastrous 1960 constitution.

The bottom line is that there are few reasons and lots of risk in rushing to dissolve the partition. Of course, no one is proposing this, although it seems to be the demand by the hawks on the Greek Cypriot side.

However, with time, and progress toward EU accession on the Turkey's side, both North and South Cyprus will become de facto united as members of the EUassuming the North obtains recognition. With EU accession, all Cypriots could enjoy and do business throughout Cyprus. Of course, EU accession is a long time away for Turkey, much less North Cyprus. However, that time could be profitably exploited to get the North's economy up to matching the South's and otherwise reduce the need for derogations accompanying the North's entry.

There are two steps to help the North toward accession. First, the Turkish Cypriot side should agree to relinquish all of the land proposed in the Annan Plan, and more. This will allow the bulk of the displaced Greek Cypriots to return to their properties. Some of those remaining would be sorely disappointed, but they would have to accept it. Offsetting this disappointment would be the cost of moving a large number of Turkish Cypriots from their homes, as well as the non-compensation of Turkish Cypriots displaced into enclaves. Perhaps the international community could devise a system of compensation for both groups, but for reasons mentioned above, a system of compensation is likely to cause more pain than gain with every decision. Instead, a related component of this agreement would be dropping of all court cases related to property lost by all sides from 1963 through 1974. After the proposed land return, both sides have to accept their losses and move on. 
Second, in exchange, the international community would agree to recognize the "TRNC." This would be a necessary precondition for its entry into the EU. With a substantial return of land, and recognition and accession for the North, the Cyprus problem would essentially be solved.

\section{References}

Attalides, M. (1979) Cyprus. New York: St. Martin's Press.

Betts, Richard K. (1994) The Delusion of Impartial Intervention. Foreign Affairs 73:20-33.

Birgisson, Karl. (1993) United Nations Peacekeeping Force in Cyprus. In The Evolution of UN Peacekeeping: Case Studies and Comparative Analysis, edited by William J. Durch. New York: St. Martin's Press.

Bloom, Mia, And Roy Licklider. (2004) Living Together after Ethnic Killing: Exploring the Chaim Kaufmann Argument. Security Studies 13(4):219-229.

Brown, Michael E. (1997) The Causes of Internal Conflict: An Overview. In Nationalism and Ethnic Conflict, edited by Michael E. Brown. Cambridge: MIT Press.

Bryant, R. (1998a) Educating Ethnicity: On the Cultures of Nationalism in Cyprus. PhD Disscussion, University of Chicago.

Bryant, R. (1998b) An Education in Honor: Patriotism and the Schools of Cyprus. In Cyprus and Its People: Nation Identity, and Experience in an Unimaginable Community, 1955-1997, edited by Vangelis Calotychos. New York: Westview Press.

Calotychos, Vangelis. (1998) Interdisciplinary Perspectives: Difference at the Heart of Cypriot Identity and Its Study. In Cyprus and Its People: Nation Identity, and Experience in an Unimaginable Community, 1955-1997, edited by Vangelis Calotychos. New York: Westview Press.

Crawford, Beverly. (1998) The Causes of Cultural Conflict: An Institutional Approach. In The Myth of 'Ethnic Conflict:' Politics, Economics, and 'Cultural Violence', edited by Beverly Crawford and Ronnie D. Lipschutz. Berkeley: University of California.

“Cyprus 'Spurns Historic Chance’” (April 25, 2004) BBC News. Available at http://news.bbc.co.uk/1/ hi/world/europe/3656753.stm. Accessed February 26, 2007.

Fearon, James D. (2004) Separatist Wars, Partition and World Order. Security Studies 13(4):394-415.

Fearon, James D., And David D. Laitin. (1996) Explaining Interethnic Cooperation. American Political Science Review 90:715-735.

Fouskas, Vassilis K. (2005) Uncomfortable Questions: Cyprus, October 1973, August 1974. Contemporary European History 14:45-63.

Gettleman, Jeffrey. (April 3, 2006) "Sectarian Strife Fuels Gun Sales in Baghdad." New York Times. "The Global Menace of Local Strife" (May 22, 2003) Economist. Available at http://www.econ omist.com/world/na/displayStory.cfm?story_id $=1795830$

“The Global Menace of Local Strife” (May 22, 2003) Economist. Available at http://www.econ omist.com/world/na/displayStory.cfm?story_id=1795830. Accessed February 26, 2007.

Harbottle, Michael. (1975) The Blue Berets. London: Leo Cooper.

Jervis, Robert. (1978) Cooperation Under the Security Dilemma. World Politics 30:167-214.

Johnson, Carter. (2006) Sovereignty or Demography? Reconsidering the Evidence on Partition in Ethnic Civil Wars. Paper version 3.1, University of Maryland, College Park, MD.

Joseph, Joseph S. (1997) Cyprus: Ethnic Conflict and International Politics: From Independence to the Threshold of the European Union. $2^{\text {nd }}$ edition. London: MacMillan Press.

Kaufman, Stuart J. (1996) Spiraling to Ethnic War: Elites, Masses, and Moscow in Moldova's Civil War. International Security 21:108-138.

Kaufmann, Chaim. (1996) Possible and Impossible Solutions to Ethnic Civil Wars. International Security 20:136-175.

Keefe, Eugene K., And Eric Solsten. (1993) Historical Setting. In Cyprus: A Country Study. $4^{\text {th }}$ edition. edited by Frederica M. Bunge. Washington: American University Press.

Knickmeyer, Ellen. (March 29, 2006) Thousands of Iraqis Flee to Avoid Spread Of Violence: Fear, Threats Push Muslim Sects Apart. Washington Post.

Kumar, Radha. (1997) The Troubled History of Partition. Foreign Affairs 22-34.

Kuperman, Alan J. (2004) Is Partition Really the Only Hope? Reconciling Contradictory Findings About Ethnic Civil Wars. Security Studies 13(4):314-349.

Laipson, Ellen. (1993) Government and Politics. In Cyprus: A Country Study. $4^{\text {th }}$ edition. edited by Frederica M. Bunge. Washington: American University Press.

Laitin, David D. (2004) Ethnic Unmixing and Civil War. Security Studies 13(4):350-365. 
Leonidou, John. (April 5, 2006) “Most Greek Cypriots 'Don't Want to Live with Turkish Cypriots.'” Cyprus Mail. Available at http://www.cyprus-mail.com. Accessed February 26, 2007.

LindleY, DAN. (1997) UNFICYP and a Cyprus Solution: A Strategic Assessment. M.I.T. DACS/Security Studies Program Working Paper, Massachusetts Institute of Technology, Cambridge. Available at http://www.hri.org/forum/intpol/UNFICYP/. Accessed February 26, 2007.

Lindley, Dan. (1999) The Military Factor in the Eastern Mediterranean. In Cyprus, the Need for New Perspectives, edited by Clement Dodd. Huntington, UK: Eothen Press.

Lindley, Dan. (2001) Assessing the Role of U.N. Peacekeeping Force in Cyprus. In The Work of the U.N. in Cyprus: Promoting Peace and Development, edited by Oliver P. Richmond and James Ker-Lindsay. New York: Palgrave/St. Martins Press.

Lindley, Dan. (2003) The Republic of Cyprus' Road to European Union Accession: Missed Opportunities to Promote a Cyprus Solution. Hellenic Studies/Études Helléniques 11:37-56.

Lindley, Dan. (2004) UNDOF: Operational Analysis and Lessons Learned. Defense and Security Analysis 20:153-164.

Mansfield, Edward D., And Jack Snyder. (1997) Democratization and the Danger of War. In Theories of War and Peace, edited by Michael E. Brown. Cambridge: MIT Press.

Markides, Kyriacos C. (1977) The Rise and Fall of the Cyprus Republic. New Haven: Yale University Press.

Meleagrou, Eleni, and Birol Yesilada. (1993) The Society and Its Environment. In Cyprus: A Country Study. $4^{\text {th }}$ edition. edited by Frederica M. Bunge. Washington: American University Press.

O’Malley, B., And I. Craig. (1999) The Cyprus Conspiracy: America, Espionage and the Turkish Invasion. New York: I.B. Tauris.

PAtrick, Richard A. (1976) Political Geography and the Cyprus Conflict, 1963-1971. Waterloo: University of Waterloo. Available at http://www.cyprus-conflict.net/patrick\%20chp\%203\%20pt\%202.htm. Accessed February 26, 2007.

Posen, BARry R. (1993) The Security Dilemma and Ethnic Conflict. In Ethnic Conflict and International Security, edited by Michael E. Brown. Princeton: Princeton University Press.

Purcell, H. D. (1969) Cyprus. London: Ernest Benn.

Roe, Paul. (2004) Which Security Dilemma? Mitigating Ethnic Conflict: The Case of Croatia. Security Studies 13(4):280-313.

Salem, Norma. (1992) The Constitution of 1960 and Its Failure. In Cyprus, A Regional Conflict and Its Resolution, edited by Norma Salem. New York: St. Martin's Press for the Canadian Institute for International Peace and Security.

Sambanis, Nicholas. (2000) Partition as a Solution to Ethnic War: An Empirical Critique of the Theoretical Literature. World Politics 52:437-483.

Stegenga, James A. (1969) The United Nations Force in Cyprus. Columbus: Ohio State University Press.

Tartter, Jean R. (1993) National Security. In Cyprus: A Country Study. $4^{\text {th }}$ edition. edited by Frederica M. Bunge. Washington: American University Press.

Theophanous, Andreas. (2003) The Cyprus Problem: Accession to the EU and Broader Implications. Mediterranean Quarterly 14:42-66.

Toft, Monica Duffy. (2003) The Geography of Ethnic Violence: Identity, Interests, and the Indivisibility of Territory. Princeton: Princeton University Press.

United Nations Peacekeeping Force in Cyprus (2005) “Cyprus.” Available at http://www.un.org/ Depts/dpko/missions/unficyp. Accessed February 26, 2007.

United States Library of Congress (2006) "Country Studies: Ethnic Demography on Cyrpus." Available at http://lcweb2.loc.gov/frd/cs/cyprus/cy02_01b.pdf

Varshney, Ashutosh. (2003) Ethnic Conflict and Civic Life: Hindus and Muslims in India. $2^{\text {nd }}$ edition. New Haven: Yale University Press.

Wendt, Alexander. (1995) Constructing International Politics. International Security 20:71-81.

Wilkinson, Steven. (2004) Votes and Violence: Electoral Competition and Ethnic Riots in India. Cambridge: Cambridge University Press.

Zurich and London Agreements (February 19, 1959) "Memorandum Setting Out The Agreed Foundation For The Final Settlement of The Problem of Cyprus." London. Available at http:// www.cyprus-conflict.net/Treaties\%20-1959-60.htm. Accessed February 26, 2007. 